\title{
Transnational Identities in Diaspora Writing: The Narratives of Vasily Yanovsky
}

\author{
Maria Rubins
}

The study of Russian émigré writing has been a vibrant academic field for almost three decades, yet the dominant critical reception of these texts remains today suffused with the glasnost-era rhetoric of a "grand return": the diaspora is described in terms of a "branch" or "tributary" destined to merge with twentieth-century Russian literature of the homeland. ${ }^{1}$ Émigré writers are routinely contextualized within the Russian literary canon in conventional terms, on the basis of country of origin and language. This hierarchical and centripetal vision of the relationship between metropolitan Russia and the diaspora presumes a preeminent relevance for exiles of the native tradition and the national master narrative, when in fact they had for many years evolved in a completely different geographical and cultural space. Migrants' narratives generally constitute a discursive field in which narrowly conceived national, ethnic, linguistic, and cultural affiliations are constantly deterritorialized and renegotiated. When applied to the younger generation of the first wave, and in particular the authors who emerged from the Russian Montparnasse circle of interwar Paris, a strictly mononational disciplinary approach would appear reductive. Informed by diverse cultural influences, their narratives systematically transcend the nationalist framework, engendering a transnational agenda and poetics. In this article, I set Russian émigré literature in dialogue with transnational theory-a productive conceptual context for the discussion of narratives marked by displacement, transcultural alienation, and hybridity.

The evolving transnational theory proposes an alternative approach to articulating group identities in today's globalized, postnational, postcolonial, and postmodernist world, in which the nation is no longer seen as a stable and monolithic category but rather an "imagined community" and even a "cultural artefact."2 However, it also provides a viable interpretive lens for assessing diverse cultural phenomena from other time periods, and in particular modernist writing born out of the experience of exile. ${ }^{3}$ One of the central categories in the lexicon of transnationalism is the boundary, and insights into its

Vasily Yanovsky used this spelling of his name after moving to the United States in 1942, and it is the name under which he published in English, hence my use of this version rather than the Library of Congress transliteration, "Vasilii Ianovskii." The research for this paper was supported in part by a grant from the Alexander von Humboldt Foundation.

1. The view of twentieth-century Russian literature as fundamentally unified was originally articulated in Gleb Struve's pioneering book Russkaia literatura v izgnanii (New York, 1956) and later reiterated at a 1978 Geneva conference titled "One or Two Russian Literatures?”

2. Benedict Anderson, Imagined Communities: Reflections on the Origins and Spread of Nationalism (New York, 1991), 4.

3. Some critics have expressed a remarkably inclusive view of transnationalism, extending it not only to the Enlightenment-era "Republic of Letters" but even much further back in time. Stephen Clingman even submits that almost any writer can be labeled transnational, although some respond more directly to the promptings of the transnational

Slavic Review 73, no. 1 (Spring 2014) 
porous and shifting nature structure the critical reexamination of further key concepts. Artistic imagination, shaped by dislocation, transplantation, and the ensuing defamiliarization of referential reality, fosters the superimposition of the realistic and the fantastic, the fusion of various national contexts, a commitment both to local and global points of view (that is, translocalism), and the creation of imaginary locations, alternate histories, and sciencefictional worlds. The plurality of migrants' experiences at various physical or mental border crossings configures their perspectives of "historical and cultural relativism." This approach, as Homi Bhabha demonstrates, reveals "other enunciatory positions" within even the most sacred texts and national master narratives. ${ }^{4}$ For Nikos Papastergiadis, the important task of "critique and resistance to the monological language of authority" is performed by the "language of hybridity," which is a legacy of migration conceived as a condition for "our ability to imagine an alternative." 5

Attributing the rise of "vernacular-based nationalisms" to the "philological revolutions" of the early nineteenth century, Benedict Anderson argues that "from the start the nation was conceived in language." If language is viewed as the most essential determinant of a national profile, then it is hardly surprising that authors with a transnational identity resist any equation of their literary personae with their native idiom. Seeking to engage in a dialogue across national fault lines, many of the iconic practitioners of transnational fiction (including Vladimir Nabokov, Samuel Beckett, Joseph Conrad, and Milan Kundera) effected a language shift in their writing. Their bilingualism, however, is not a simple exchange of one national identity for another but rather the creation of a new "space," which transcends both national contexts even as it incorporates their respective elements. The verbal practice of bilinguals reveals that the language of creative expression can simply be a matter of the author's personal artistic preference rather than a link between the particular text and a distinct national tradition or literary canon. Is bilingualism, then, a prerequisite for the evolution of a writer toward transnationalism? In the secondary literature this often seems to be a natural assumption, based on bilinguals' ostensible awareness of the plurality of codes and therefore of various ways of apprehending and expressing the world. ${ }^{7}$ As Tijana Miletic observes, "The writing of bilinguals tends to play more with the separability of sign and object ... and is generally more tolerant of ambiguities generated

agenda. Stephen Clingman, The Grammar of Identity: Transnational Fiction and the Nature of the Boundary (Oxford, 2009), 21.

4. Homi K. Bhabha, The Location of Culture (New York, 1994), 226.

5. Nikos Papastergiadis, The Turbulence of Migration: Globalization, Deterritorialization and Hybridity (Cambridge, Eng., 2000), 182, 11.

6. Anderson, 139, 145.

7. A notable exception is Eva Hausbacher's recent monograph dedicated to the transnational literary production of several contemporary Russian-born authors living in the west. Eva Hausbacher, Poetik der Migration: Transnationale Schreibweisen in der zeitgenössischen russischen Literatur (Tübingen, 2009). Only one of these authors, Wladimir Kaminer, writes in an adopted tongue (German), whereas the other three (Marina Palei, Mariia Rybakova, and Julia Kissina) use their native Russian, which does not preclude them, according to Hausbacher, from qualifying as transnational writers. See Adrian Wanner, Out of Russia: Fictions of a New Translingual Diaspora (Evanston, 2011), 11. 
from such a loose and liberated semantic attitude." ${ }^{8}$ But perhaps the transnational writer's more important asset is not bilingualism but biculturalism, that is, exposure to more than one culture (which can also affect linguistic praxis).

Evidently, there exists an alternative path to transnational identity-not by embracing a lingua franca but by expanding the proportions of the writer's native idiom far beyond conventional confines, in some cases even cultivating a deliberate "foreignness" in verbal expression. A number of migrant writers practice a kind of translingualism, enhancing the elasticity of the language, creolizing it, and creating different idiolects. They introduce a foreign linguistic reality to defamiliarize the native tongue, decoupling it from its traditional territory. Potentially translingual narratives lend themselves more easily to translation: resulting from cultural and linguistic blending and incorporating elements from various systems of signification, they are inherently translatable.

Today, critics often employ translation as a metaphor for the very process of intercultural communication. ${ }^{9}$ Discussing transnational and bilingual literary models, Azade Seyhan turns to Walter Benjamin's articulation of translation principles in his work "On the Concept of History." According to Benjamin, translation should incorporate the original language's mode of signification so that both the original and the translation can be recognized as fragments of a larger language. This larger language denotes the translatability of the original. ${ }^{10}$ Translatability thus seems an absolute requirement for any text intended to participate in intercultural interaction and the transmission of cultural memory. The most important implication of Benjamin's concept of translation for transnational literature, as Seyhan concludes, is that "translation and memory participate in the same structural mode. They are both structures of postponement, reconfigured from shards of a prior structure in a temporal (historical) continuum."11

Finally, scholars of transnational literature emphasize that it is not only created by but also addressed to "a transnational group of the like-minded" (though the empirical reader may of course differ from this ideal audience). ${ }^{12}$ The receiving consciousness thus plays an active role in investing the text with a specific meaning. "Directed towards migrant and multi-lingual communities, who exist in multiple and in-between spaces," a transnational text depends on an engaged and informed reading audience attuned to its diverse cultural codes and capable of reading it from several converging perspectives. ${ }^{13}$ National identity is thereby reshaped into an intellectual and emo-

8. Tijana Miletic, European Literary Immigration into the French Language: Readings of Gary, Kristof, Kundera and Semprun (New York, 2008), 19.

9. Papastergiadis, 131.

10. See Azade Seyhan, Writing outside the Nation (Princeton, 2001), 155.

11. Ibid., 156.

12. Katerina Clark proposes this definition in the context of the 1930s transnational artistic community that emerged in Stalinist Moscow. Katerina Clark, Moscow, the Fourth Rome: Stalinism, Cosmopolitanism, and the Evolution of Soviet Culture, 1931-1941 (Cambridge, Mass., 2011), 141.

13. Clingman, 8. 
tional, rather than geographic, affiliation, rendering it portable and easily accessible, with readers and authors forming a community whose shared culture is one of displacement and self-invention. ${ }^{14}$

As products of migration and "transfigurations ... a at cultural borders," transnational narratives are well-suited to represent the crucial nexus between "the exilic consciousness and the modern sensibility." 15 The Russian revolution sent millions into exile-arguably the first mass migration of the twentieth century. In the field of cultural production, one of the unlikely consequences of this national catastrophe was the emergence of distinct modes of transnational writing. As an emblematic cosmopolitan author, Nabokov is often credited with inspiring "writers who stand apart from national literary traditions to find a participatory, transnational community of fellow-artists." 16 While emerging from a similar branch of transnationalism, Nabokov's contemporary Vasily Yanovsky (1906-1989) represents a unique and arguably more radical voice within this canon. Until recently, Yanovsky was known to Russian readers mainly for his memoirs of interwar Russian Paris, Polia eliseiskie: Kniga pamiati (Elysian Fields: A Book of Memory, 1983). Indeed, as a chronicler of his émigré generation, he made a major contribution to Russian cultural history. But in his fiction he transcended national confines and evolved into a transnational (and eventually bilingual) writer with an original metaphysical agenda, destined for a global community of readers. As the following case study demonstrates, in his artistic medium Yanovsky anticipated questions that lie at the very core of contemporary transnationalist discourse. His texts form a dynamic corpus in which a range of alliances and solidarities are challenged and various transnational models are articulated and tested.

If transnational texts record the voices of "transplanted" individuals, Yanovsky had more than his fair share of geographical and cultural "transplantations"-from his birthplace in Poltava, to Paris via Poland, and later to New York. In this respect, he fits within the deracinated generation of the Russian literary diaspora, known alternatively as the "unnoticed generation," the "Russian Montparnasse," or the "Paris school."17 Most of these writers were born in the early twentieth century, left Russia as adolescents in the aftermath of the revolution, completed their educations in the west, and began to publish in the 1920s. Their group identity is best assessed in terms of Karl Mannheim's classic study "The Problem of Generations" (1928), in which a generation is defined not so much by the proximity of birth dates as by similar reactions to specific outside influences, especially traumatic events that shape common values, behavioral patterns, mentality, aesthetic tastes, and, ultimately,

14. Rachel Trousdale, Nabokov, Rushdie, and the Transnational Imagination: Novels of Exile and Alternative Worlds (New York, 2010), 2.

15. Seyhan, 106; Papastergiadis, 10-11.

16. Rachel Trousdale, "Nabokov and the Transnational Canon," The Nabokovian 66 (Spring 2011): 7-14.

17. Annick Morard identifies "deracination" as the chief aspect of the generational identity of the "sons" of the first wave of emigration in her book De l'Émigré au déraciné: La "jeune génération" des écrivains russes entre identité et esthétique (Paris, 1920-1940) (Lausanne, 2010). The "unnoticed generation" formula was coined by Vladimir Varshavskii in his Nezamechennoe pokolenie (New York, 1956). 
a sense of solidarity ${ }^{18}$ From this perspective, the "unnoticed generation" can even be viewed as a specific Russian émigré variation on the "lost generation," the transnational community of expatriates who settled in Paris in the 1920 s and whose sensibilities and uncompromising creativity were informed by the trauma of a global war, an ensuing existential crisis, and the abrupt break with the prewar aesthetic tradition.

Russian Montparnasse output generally transcended the national parameters outlined by mainstream émigré discourse and fed into a range of contemporary transnational aesthetic trends. ${ }^{19}$ Whereas the older representatives of the Russian diaspora focused on their "mission" as the self-proclaimed guardians of "classical" Russian culture, producing texts punctuated by passéisme and rendered in an ostensibly "pure" idiom (i.e., unpolluted by Soviet neologisms or foreign borrowings), the younger writers' identity was hybrid, bicultural, and bilingual, with only vague memories of Russia and a greater intellectual and emotional engagement with their host country. Apart from occasional early works drawing upon impressionistic recollections of civil war turmoil (such as Gaito Gazdanov's Vecher u Kler [An Evening with Claire, 1929] and Yanovsky's Koleso [The Wheel, 1930]), Russian Montparnasse narratives were oriented thematically toward contemporary Europe. Rather than following the artistic precepts of the older generation, these authors engaged in bold experimentations with western artistic trends, incorporating into their work elements of Dada, surrealism, existentialism, and the physiological style (as practiced by Louis-Ferdinand Céline and Henry Miller). In their main publishing venture, the journal Chisla, the Montparnasse writers debated European modernism and the Soviet avant-garde with equal enthusiasm. Rather than seeking literary models in the nostalgic prose of Ivan Bunin, Ivan Shmelev or Boris Zaitsev, the Paris School turned to Marcel Proust, André Gide, Franz Kafka, James Joyce, Georges Bataille, and other western authors and philosophers.

Henri Bergson occupied a special place in the younger émigrés' aesthetic and philosophical self-definition: the French thinker's theories offered an escape from what they perceived as metaphysical collapse. A convincing case has been made for an affinity between early Russian modernism and Berg-

18. Karl Mannheim, "The Problem of Generations," in Paul Kecskemeti, ed., Essays on the Sociology of Knowledge (London, 1952), 276-322.

19. The exploration of Russian Montparnasse writing in the context of western cultural and literary phenomena was initiated in Leonid Livak, How It Was Done in Paris: Russian Émigré Literature and French Modernism (Madison, 2003); J.-Ph. Jaccard, A. Morard, and G. Tassis, eds., Russkie pisateli v Parizhe: Vzgliad na frantsuzskuiu literaturu, 1920-1940 (Moscow, 2007); S. A. Isaev, Siurrealizm i avangard: Materialy rossiisko-frantsuzskogo kollokviuma (Moscow, 1999); Svetlana Semenova, "Ekzistentsial'noe soznanie v proze russkogo zarubezh'ia (Gaito Gazdanov i Boris Poplavskii)," Voprosy literatury (May-June 2000): 67-106; Aleksei Chagin, ed., Gaito Gazdanov v kontekste russkoi i zapadnoevropeiskikh literatur (Moscow, 2008); L. V. Syrovatko, ed., Gazdanov i mirovaia kul'tura: Sb. Nauchnykh statei (Kaliningrad, 2000); Dmitrii Tokarev, "Mezhdu Indiei i Gegelem": Tvorchestvo Borisa Poplavskogo v komparativnoi perspektive (Moscow, 2011); Morard, De l'Émigré au déraciné. 
sonian philosophy. ${ }^{20}$ But Bergson's ideas about the limitations of rationality, the need to combine intellect with introspection, the importance of intuition, the free cosmic creative impulse (élan vital), and especially his concept of two kinds of time and memory particularly resonated with the weltanschauung of the post-crisis generation, who were disillusioned with the positivism and social determinism espoused by their predecessors. The vision of reality as a durée réelle, a ceaseless state of becoming, unconstrained by time's irreversible linearity and distinguished by a harmonious confluence of past and present, offered an effective remedy against the pervasive trappings of nostalgia. Bergson's insights into the special role of memory pointed the way to lifting the "deceptive veils of reality" and bridging the gap between matter and spirit. Furthermore, the younger generation found appealing the optimism of Bergson's essentialist philosophy and the value he placed on the surrounding material world. ${ }^{21}$

Indeed, immediate reality fascinated the authors of the Russian Montparnasse circle, who repudiated their older peers' disregard for the rich cultural scene of interwar Paris. Hailed as the cultural capital of the world, the city became not only the heartland of transnational literature but also a shared code for the multilingual corpus of narratives penned by French and expatriate writers of the postwar generation. These authors projected their existential anxiety and experience of displacement and marginality onto Parisconceived of as the archetypal alienating urban metropolis and a locus of modernity and creativity. In the metadiscourse of Russian writers, the city systematically asserts itself as a particular aesthetic context rather than a distinct geographical or cultural reality (i.e., the capital of France, or a city showcasing French culture). In an article titled "Around Chisla," the leader of Russian Montparnasse group, Boris Poplavskii, defines Paris as the true "homeland" of émigré literature, insisting on the uniqueness of his fellow writers' "Parisian experience," which is "neither Russian nor French."22

Reminiscing in a later interview about his formative years in Paris, Yanovsky stressed cultural fusion as the main mode of his generation's aesthetic activity: "What we did in Paris was, in a way, a synthesis of the best

20. "Bergson's compatibility with Russian thought . . . owes much to ... the tradition of Orthodox ontologism in Russia, whereby the theory of knowledge is considered valuable only when serving as part of our total activity of 'being' in the world. Thus the intertwining in Russian culture of metaphysics, aesthetics, religion and science into an organic Whole (expressed most clearly perhaps in Solov'ev's conception of 'all-unity'), which crystallizes into the Russian concern with the primary link between art and life, art serving both as a way of knowing and transforming reality (a concern once again found in Solov'ev, who stresses the theurgic role of art).” Hilary L. Fink, Bergson and Russian Modernism, 1900-1930 (Evanston, 1999), 112.

21. Michael Glynn, for example, suggests that Nabokov was particularly attracted to Bergson's exposure of "man's apparent tendency to misperceive ... reality.” In his study, Glynn traces Nabokov's explorations of such misconceptions' "rich implications," which were repeatedly thematized in his works, back to Bergson's initial influence. Michael Glynn, Vladimir Nabokov: Bergsonian and Russian Formalist Influences in His Novels (New York, 2007), 57.

22. Chisla, no. 10 (1934): 204-9. 
from Russian culture with the best western or, more precisely, European culture." ${ }^{23}$ As opposed to many older émigré writers, who passionately advocated cultural purity, Yanovsky did not question the creative potential of such a synthesis. Born in the Pale of Settlement, on the margins of the Russian empire, he was from the outset the product of a peripheral and inevitably hybrid, multivocal, and dialogic cultural environment. Apart from reading the classics from an early age, he was not reared with refined Russian culture: he did not grow up in Silver Age Petersburg and was not surrounded by the poetic atmosphere of a traditional country estate, the legacies of which sustained other writers abroad. It was Parisian exile that gave Yanovsky direct access not only to the western avant-garde but also the Russian intellectual tradition, and he took full advantage of the soirées organized by the Merezhkovskiis and the Green Lamp society, the energetic debates at Il'ia Fondaminskii's religio-philosophical circle Krug, Mikhail Osorgin's mentorship, and so on. Unsurprisingly, Russian and western influences blended in his own writing. The situation was not all that different for other members of the "unnoticed generation," however: while some had spent part of their childhoods in cultural centers (Poplavskii and Varshavskii in Moscow, and Gazdanov in St. Petersburg, for example), they began to write only in late-1920s Paris, having passed through other European countries on their way. Not embedded in any well-defined, stable, and "pure" milieu, their formative experiences were ones of perpetual dislocation, defined by a dynamic cultural mosaic. Their habitual crossing of geographic boundaries from an early age naturally translated into the cultural, linguistic, and mental border crossing evident in their fiction.

Yanovsky's Parisian works, like those of other authors of his generation, illustrate the general shift in interwar prose away from the novel and toward autobiographical, testimonial, and introspective modes of writing reminiscent of a "human document." Discarding literature in its conventional (imaginative and fictional) form, the Paris school's metadiscourse advanced such key notions as seriousness, truth, simplicity, confession, honesty, and selfreflection. A typical human document presented an ostensibly unmediated first-person account of real-life experiences, with an unpolished, fragmentary, and incoherent style, a lack of closure, provocatively explicit language, and the absence of conventional rhetorical devices corroborating authenticity for the reader. The thematic repertoire (alienation, loneliness, the absurdity of existence, suffering, death, physical and moral decay, and occasional necrophilia) appealed to the postapocalyptic sensibilities of a generation shocked by the atrocities of the Great War and consumed with existential anxiety.

Yanovsky paid tribute to the human document genre in his own way, indulging in graphic descriptions of tumors, autopsies, surgery, and all kinds of physical and moral human waste, using obscene vocabulary and twisting Russian syntax far beyond accepted norms. His penchant for physiological detail was a reflection, no doubt, of his medical profession (he received a physician's

23. Interview by Iu. Troll. Bakhmeteff Archive of Russian and East European Culture (BAR). Ms Coll. Vasily Yanovsky. Box 17: Arranged Manuscripts. Yanovsky, Vassily Semenovich. 
diploma from the Sorbonne in 1937) but also of the cult of Céline, whose novel Voyage au bout de la nuit (1932) provoked lively debates in émigré circles and whose themes were echoed in Russian Montparnasse fiction. ${ }^{24}$ Discussing the resonance between Yanovsky's style and Céline's, Leonid Livak states that the popularity of Voyage legitimized Yanovsky's "esthetics of disintegration" in the eyes of diaspora critics, who had initially been unenthused by the young writer's violation of norms of propriety and grammatical rules. ${ }^{25}$

What distinguishes Yanovsky's panorama of an absurd and dehumanized world from the typical interwar human document is his persistent attempt to grasp the meaning of individual existence and uncover a metaphysical scenario behind the apparent unpredictability of life and death. Dying without coming to this realization constitutes a tragic failure: "Thus died Kurlov the student, never knowing why he was born," concludes the narrator of "Zhizn' i smert' studenta Kurlova" (The Life and Death of Kurlov the Student). ${ }^{26}$ This spiritual quest, originally inspired by discussions at Krug, a society with Christian leanings, was Yanovsky's way of transcending the existentialist nihilism that underpinned the interwar generation's ethos. Furthermore, it allowed him to integrate elements from Russian literary classics (in particular, their master plot of spiritual salvation through suffering) with the aesthetics of disintegration that flourished in contemporary writing. As Livak points out, Yanovsky's conflation of Christian pathos and a negative portrayal of humanity's spiritual condition paralleled some western intellectuals' (mis)reading of Céline. Turning a blind eye to his cynicism and antireligious stance, French Catholic critics claimed that Céline's protagonist's "calvary recalled the physically repellent yet expiating nature of Christ's suffering." Viewed from this perspective, "Voyage proved that the world could be saved through Christian love, which would flare up at the sight of extreme suffering; showing the modern human condition, Céline stirred compassion for humankind."27 This unlikely identification of Céline's earthly hell as a necessary stage on the road to salvation was echoed by some Russian émigré critics who embraced a Dostoevskiian ethos. For Yanovsky, these religious-literary, Russian-French, Catholic-Orthodox, classical-avant-garde streams fused into a hybrid agenda, one that transcended any specific national framework.

24. Gazdanov gave a reading at an evening organized by the literary group Kochev'e dedicated to Céline on 7 December 1933. Georgii Adamovich, Vladimir Varshavskii, Vladimir Veidle, Mark Slonim, Iurii Fel'zen, and others took part in the subsequent discussion. The novel was actively reviewed in the émigré press: for example, L. Kelberin, Chisla, no. 9 (1933): 223-24; Yu. Terapiano, Chisla, no. 10 (1934): 210-11; G. Adamovich, Poslednie novosti, 27 April 1933, 3, and 14 December 1933, 3. Two Russian translations appeared promptly in 1934 by Elsa Triolet and Sergei Romov.

25. Livak, 142. Characteristically, Yanovsky retrospectively deemphasizes any direct influence from Céline, explaining the parallels by their common "humanitarian" outlook: "Later [Nikolai] Berdiaev sort of accused me of imitating Céline ... But we were both ... physicians of the Paris school, and I saw a lot of what he saw, and we could have similar reactions to poverty, pain, and privation. I don't think that I was under Céline's influence..." BAR: Ms Coll. Yanovsky Box 17.

26. Written in the late 1920s, "Zhizn' i smert' studenta Kurlova” was first published in Za svobodu!, n.d. (ca. 1928), under the pen name "Tseianovskii."

27. Livak, 138. 
One of Yanovsky's first sustained attempts at transforming the human document by introducing the theme of religious awakening came in the novella Liubov' vtoraia (Second Love, 1935). It is written in the form of a diary, found after the heroine's death on the operating table, and can be grouped with other contemporary first-person narratives representing the exilic experience from a female perspective, such as Nina Berberova's Akkompaniatorsha (The Accompanist, 1935) and Ekaterina Bakunina's Telo (The Body, 1933). However, Yanovsky departs from this paradigm: his heroine, driven to the brink of suicide, undergoes a sudden spiritual transfiguration when she climbs the tower of Notre-Dame de Paris, a sacred (symbolically "high") place. ${ }^{28}$ As a result of this enlightenment, her belief in God, the holiness of life, and the unity of the world is miraculously restored.

Contemporary critics found the Notre-Dame scene utterly unconvincing and out of place in a narrative whose main focus was, after all, entropy rather than spiritual euphoria; ${ }^{29}$ the writer's selection of an ancient and sacred Parisian site, however, suggests a twofold agenda. First, by designating NotreDame the city's spiritual peak, in counterbalance to the hellish metropolitan abyss, Yanovsky challenges the typical human document, which is concerned with the physiological depiction of the urban underbelly. The city that opens before the heroine's view from the bell tower suddenly acquires integrity; instead of a haphazard agglomeration of fetid neighborhoods, she sees a majestic panorama of Paris unfolding from the snow-white Sacré-Coeur to the north, toward the Arc de Triomphe in the west, and the ancient church of Saint-Germain-des-Prés on the left bank of the Seine River. However, this is not an accurately reconstructed tableau of Parisian architectural monuments in the vein of the nineteenth-century genre of literary panorama but a "celestial blueprint" of Paris withdrawn from the physical world, "a muffled city, longabandoned by mortals-bleached, without rigid outlines, enlightened." 30

Furthermore, Notre-Dame is the archetypal locus of Catholicism, thereby representing one of the fundamental values not only of France but also of western Europe. By emphasizing its role in his heroine's spiritual transformation, the author validates a more universal European identity for the Russian émigré. ${ }^{31}$ In addition, the graphic representation of the heroine's epiphany sug-

28. Yanovsky chose the title "Preobrazhenie" (Transfiguration) for the excerpt from Liubov' vtoraia that was published in Sovremennye zapiski 53 (1930).

29. See reviews by Gleb Voloshin, Sovremennye zapiski 59 (1935): 476-77; Zinaida Schakhovskoy, "L'amour second (en russe)," Le Thyrse, 1 October 1935; Vladislav Khodasevich, Vozrozhdenie 22 (August 1935); Alfred Bem, Mech 29 (September 1935).

30. Vasily Yanovsky, Liubov' vtoraia: Parizhskaia povest' (Paris, 1935), 105.

31. Notre-Dame, as represented in French Romantic literature (Victor Hugo, Théophile Gautier, Gérard de Nerval, etc.) served as a powerful symbol of Christianity and even an icon of Christian chastity, in contrast with the heathen spirit of other Parisian buildings designed in styles inspired by Greek antiquity (Gautier's “Notre Dame” [1931]). While echoing this rich tradition, Yanovsky's narrative can also be traced to Osip Mandel'shtam's "Notre Dame" (1913), in which the poet celebrates the cathedral as an inclusive and ubiquitous monument that fuses and reconciles all religions, cultures, and styles: "Primordial labyrinth, inscrutable forest, / rational abyss of the gothic soul, / Egyptian power, Christian modesty ..." Osip Mandel'shtam, Complete Poetry of Osip Emilevich Mandelstam, trans. Burton Raffel and Alla Burago (Albany, 1973), 53. 
gests Yanovsky's intention to integrate references not only to a pan-European creed but also the mythological heritage intertwined with and within the European territory. Without abandoning his signature physiological style, he conveys the heroine's spiritual rebirth through the tropes of intercourse and childbirth. This portrayal of transfiguration, in which a "second" (that is, divine) love descends upon the heroine, taking hold of her entire physical being, echoes the iconographic tradition depicting the rape of a mortal woman by a god disguised as golden rain (the myth of Danaë, as interpreted by Rembrandt van Rijn, Titian, and François Boucher, among others). Yanovsky plies suggestive similes and metaphors as the heroine, suddenly overpowered by a "radiant column not of this world," searches for exact words with which to describe her mystical, yet very physical, experience: "A powerful Spirit was pouring into me"; "A stream rushed at me, hitting my chest"; "Flames roared through my entire body. A whistling hurricane penetrated me.... I was lying surrendered, eyes closed ..."; "Soaked in relieved unharnessed tears, with a ringing in my ears, smitten, weakened like a woman in labor." 32 The heroine's actual pregnancy, resulting from her rape by a random acquaintance a few months earlier and about which the reader learns only after the Notre-Dame episode, reinforces the parallels of this transformative experience with sexual intercourse and childbirth (while possibly also travestying the Christian dogma of the Immaculate Conception). By fusing the topos of Europe with a Russian émigré human document and emphasizing spiritual ascent and catharsis (inspired by a Catholic rather than Russian Orthodox context), Liubov' vtoraia emerges as a hybrid text that exploits multiple viewpoints.

For Yanovsky, who deemphasized his Jewish origins, Christianity as a world religion provided a flexible framework for a more universal, transnational identity. ${ }^{33}$ In the absence of any family connection, he embraced Christianity of an ecumenical sort, beyond specific denominations and sectarian divisions and inclusive of many other spiritual systems. Although Yanovsky actively drew on Christian rhetoric in his fiction and nonfiction, his spiritual

32. Yanovsky, Liubov' vtoraia, 109-10.

33. This reticence to identify as a Jew sometimes reached truly extreme proportions. Yanovsky, who reputedly lost two sisters in the Shoah and escaped a likely death by boarding a transatlantic boat in 1942, did not openly address the Holocaust in his writing. There is, however, a suggestive scene in his novel Amerikanskii opyt (1982) describing what appears to be a brutal massacre of the residents of a shtetl. Nonetheless, Yanovsky not only omits any specific references to Jews, he never even uses the word Jew, instead referring to the victims of the German firing squad simply as "men with black beards." There is, however, no evidence that Yanovsky ever formally converted to Christianity. Both of his wives were Jewish, and his older sister Bronia, who also immigrated to New York, maintained a certain level of religious observance all her life. Yanovsky's only daughter, Maria, born in August 1940, was baptized on 20 May 1941 at the Orthodox church in Marseille (Eglise Orthodoxe de la Résurrection du Christ). In the context of the Nazi occupation of France and the intensification of racial and antisemitic legislation in the "free" and occupied zones alike, this may be seen as an attempt to avoid persecution. (Conversions of apatrides of Jewish background were quite common around this time; Irène Némirovsky's case is a salient example.) Later, in America, Yanovsky espoused a liberal version of Christianity that apparently corresponded to his self-assessment as a man of world culture. He was buried at the Novo-Diveevo Russian Orthodox cemetery in New York State. 
quest eventually led him far beyond any rigid canonical interpretations. Reminiscing about her first encounter with Yanovsky at a meeting of the Fondaminskii circle, Elena Izwolsky writes, "Even then he was concerned, as in later years, with the relationship of flesh and soul, of matter and spirit, and with the meaning of the medical profession." ${ }^{34}$ Alluding to the title given posthumously to Nikolai Fedorov's teachings, Filosofia obshchego dela (The Philosophy of the Common Task), she defines their "experience of the Paris days" as "the quest for humanism, social justice, and the transfiguration of a grossly material world through transcendent philosophy as well as action. And such are themes of Yanovsky's writings. In his books the reader finds, side by side, the stark reality of our times and ... the hope that one may defeat a mechanized and automatic civilization by a loving and gentle relationship in the name of "the common task." 35

Yanovsky's interest in issues of global import led him steadily away from a distinct national point of view in his fiction, in which he avoided a thematic focus on Russia, the revolution and civil war, or the Russian émigré experience. Even if occasional characters featured in his texts written after the mid-1930s can be identified as Russian exiles, their exilic status is used not to explore any Russia-specific historical, political, cultural, or psychological dimensions of exile but as a metaphor for the condition of modernity. In this sense, the novel Portativnoe bessmertie (Portable Immortality, 1953) marked Yanovsky's transition to another, more abstract model of transnational writing. He began Portativnoe bessmertie in the late 1930s, but the work was interrupted by the outbreak of World War II, the occupation of France, and another forced migration-this time to New York. During the years that followed, Yanovsky faced many challenges: adapting to an unfamiliar, American way of life, assimilating the English language, and reinventing himself once more in a new cultural and social environment.

Despite the difficult initial adjustment to his new host country, he was fortunate to join a New York-based circle of like-minded cosmopolitan intellectuals which coalesced around the ecumenical society the Third Hour, created by Izwolsky in the mid-1940s. The Third Hour quickly outgrew the format of yet another association of Russian émigrés. Along with Arthur Lourié (Artur Lur'e), Aleksandr Kazembek, and Aleksandr Kerenskii, scores of international participants attended its meetings, including W. H. Auden, Denis de Rougemont, Anne Fremantle, Ursula Niebuhr, Dorothy Day, and many other writers, philosophers, politicians, and priests who had migrated to New York from all over the world. The members of the Third Hour constituted a vibrant trans-

34. Elena Izwolsky, "V.S. Yanovsky: Some Thoughts and Reminiscences," TriQuarterly 28 (Fall 1973): 28, 490-92, 492.

35. Izwolsky, 492. Fedorov argues for the need for humanity to devote all creative energy to the task of resurrecting dead ancestors, taking control over nature (including human nature) and the cosmos, and thereby restoring the world to its intended perfection, "seeing God face to face," and realizing eternal and universal happiness. Published by Fedorov's disciples in 1906 in Vernyi (now Almaty, in Kazakhstan), the first edition was a two-volume miscellany, 1,200 pages long, and comprised of short essays, both finished and unfinished. 
national community with a common platform articulated in its eponymous journal, which was first published in 1946 and endured for thirty years:

\begin{abstract}
Against the background of conflicting intellectual trends and tragic worldevents, we continue to seek testimonies and expressions of authentic religious and human experiences. We believe that such testimonies in the field of religious life, as well as in literature, poetry and art, exemplify the working of spiritual forces without which the challenge of our time cannot be met. This is the great adventure of dedication and brotherhood to which our generation more than ever seems to be called: a personal call addressed to each, but in the name of all. ${ }^{36}$
\end{abstract}

The ethos of this uprooted intellectual elite resonated with Yanovsky's own quest for the spiritual unification of mankind. At the same time, his active participation in Third Hour meetings and his work as contributor to and coeditor of the group's journal became instrumental in furthering his philosophical self-definition and informing the thematic repertoire of his writing for decades to come.

The hybrid nature of Portativnoe bessmertie reflects these important junctures in Yanovsky's personal and creative development. The bulk of the novel is reminiscent of an interwar human document. It lacks a well-defined plot and consists of lengthy fragments loosely stitched together by the first-person narrator, whose passionate monologues on random subjects follow in an incoherent stream of consciousness. This homodiegetic narrator-practically undistinguishable from the author-is a young émigré doctor who lives on the outskirts of Paris, treats poor patients, and seeks no professional advancement. His attitude resonates with the defeatist credo of the unnoticed generation, articulated by Poplavskii: "After all, the most beautiful thing on earth is to be a genius and to die in obscurity." 37

The protagonist's peripheral location shapes his skewed vision of the city, which is dramatically at odds with its image of the glamorous "world capital" of the Jazz Age. Nor does this panorama of a decaying city correspond to the myth of the French capital long cultivated in Russian culture. Even the classic tourist itinerary, from the Latin Quarter to the rue de Rivoli, is presented in the novel through a grotesque catalogue of hospitals, morgues, pissoirs, and prisons. Rain forms a permanent backdrop, blurring outlines and washing away colors. As a metaphor for subconscious, irrational, dream-like states and the flow of time, water figured prominently in surrealist descriptions of Paris (for example, Philippe Soupault's Les dernières nuits de Paris [1928], Gazdanov's “Vodianaia tiur'ma” [1930], and Poplavskii’s Apollon Bezobrazov [1930]). Liberally drawing on the surrealist lexicon, Yanovsky records several uncanny aquatic dreams. Expressions like "time was dripping above our heads [vremia kapalo nad golovami]" recall not only literary but also visual intertexts, such as Salvador Dali's paintings of melting clocks. But Yanovsky routinely inverts the connotations of surrealist aqua-tropes. Rather than standing for the mys-

36. “To Our Readers,” Third Hour, no. 5 (1951): 1.

37. Boris Poplavskii, "O misticheskoi atmosfere molodoi literatury v emigratsii," Chisla, no. 2-3 (1930): 311. 
tical state of prenatal reverie, torrents of water are associated in his novel with unsavory lavatories, gutters, and tanks for the preservation of corpses. ${ }^{38}$

The explicit physiological vocabulary of Portativnoe bessmertie, the émigré protagonist, the grotesque visions of Paris corresponding to the tonality of the interwar Paris-text, the sense of existential despair, and the overall style establish expectations of an extreme human document. However, having created a world beyond salvation, toward the end of the novel the author transcends the familiar genre by introducing a more positive scenario. To an even greater extent than in Liubov' vtoraia Yanovsky resorts to a deus ex machina, but this time the ecstatic quasi-religious discourse is camouflaged by a dynamic plot with utopian and even science fiction elements (though of a rather naive variety), one markedly unlike Russian Montparnasse writing. The protagonist joins a group of idealists of diverse ethnic origins headed by Jean Doute, who invents a mechanism that emits miraculous Omega rays. The activists discreetly point their machine at random people, instantly transforming them into kind and compassionate individuals. This ending led some critics to dismiss the novel as depicting a "hopeless utopia" and even a work of "obvious delirium." ${ }^{39}$ However, Yanovsky's ironic ambivalence toward this dubious Eden is suggested by the portrayal of the opposition to Jean Doute and even the semantics of his name, which is homophonous with the French phrase j'en doute (I doubt it). The entire Omega ray scheme could be read as a travesty of the rationalistic systems for manipulating human nature that proliferated in the first half of the twentieth century, from communism and fascism to behaviorism. ${ }^{40}$

This story of mass irradiation also polemically engages with Aleksei Tolstoi's novel Giperboloid inzhenera Garina (Engineer Garin's Death Ray, 192527). ${ }^{41}$ The motif of mysterious "rays" had been a popular one in science fiction at least since the publication of H. G. Wells's The War of the Worlds (1898). Public imagination was periodically stirred by sensational news about the invention of deadly rays, and in 1925 Goskino capitalized on this massive obsession by releasing the scientific fantasy film Luch smerti (The Death Ray, dir. Vladimir Gardin). The same year, René Claire completed his cinematographic fantasy Paris qui dort (or Le Rayon de la mort), which shows the city plunged into catalepsy by a mad scientist projecting an immobilizing ray from his laboratory. Yanovsky's reanimation of this thematic cliché in his novel suggests

38. "In the dark cellars of the medical school ... running water gurgles. Corpses are kept there under spigots; dead bodies float in deep tanks." Vasily Yanovsky, Portativnoe bessmertie (Moscow, 2012), 477. Cf. Marie-Claire Bancquart, Paris des Surréalistes (Paris, 1972), 57.

39. V. R. "Sredi knig i zhurnalov: Vasily Yanovsky.-'Portativnoe bessmertie,"” Vozrozhdenie 63 (1957): 125-27.

40. More recently, critics have tended to read the novel as an anti-utopia. Iu. V. Linnik, "Filosofskie iskaniia v proze Vasiliia Ianovskogo," New Review 194 (1994): 207.

41. Both books describe a pseudo-scientific discovery that potentially gives the inventor and his close associates superhuman powers, and both portray an ideological collision between two opposing groups who compete for world domination. However, in Yanovsky's work the rays' purpose is to prompt people to "merge in communal joy [slit'sia $v$ sobornoi radosti]," whereas in Tolstoi the rays become a weapon of mass destruction. 
his intention to present a philosophical and spiritual agenda in the guise of a popular genre, while rendering it in the transnational artistic language of the interwar period.

Besides contemporary fiction and popular culture, Portativnoe bessmertie's influences can be traced to diverse intellectual sources, including Pierre Teilhard de Chardin's concept of the Omega Point. Teilhard de Chardin, who was an important influence on the unnoticed generation and whose views later found their way into the Third Hour journal, defines the Omega Point as the locus of supreme consciousness and the ultimate destination for the evolution of all creation. Yanovsky's writing, especially in his later period, suggests that he harbored a utopian belief in the possibility of common global consciousness, not unlike Teilhard de Chardin's noosphere.

To a great extent, Yanovsky's agenda reflects traditional Russian questions about the feasibility of "God's kingdom on earth" which were reinvigorated by émigré thinkers and debated in the Krug and Novyi grad societies. According to Vladimir Varshavskii, Yanovsky developed this problem in his novel in the context of Fedorov's and Bergson's ideas about the "relationship between mysticism and machinery." ${ }^{\prime 2}$ Both philosophers fascinated Yanovsky throughout his life. In his articles on Fedorov he emphasizes the particular relevance of his philosophy of action for the present: "Nikolai Fedorov ... did not confine himself to an analysis of the situation but pointed out the way to save humanity by unifying it around one common cause-the fight against poverty, disease, death and, in the last count, the cause of resurrection of our dead forefathers." ${ }^{43}$ The protagonist of Portativnoe bessmertie occasionally concludes his philosophical musings with rather transparent references to Fedorov, as in the following example:
And maybe the essence is exclusively in the nucleus, a seed, a kernel, trans- mitted from generation to generation, taking on flesh once again, enriched with new small cuts (reflection, biography). Always identical (only at dif- ferent levels), a clinging immortal seed, with a mind of its own, temporar- ily connected with my appearance ... How can I separate myself from my precursors, squeeze out brothers, grandfathers, great-grandfather, are we all-one, am I-everyone ... If I could split the nucleus and take them out, as if from a toy egg, one after another, ever tinier, a long succession all the way to Adam. ${ }^{44}$

Here, the protagonist apparently contemplates one of Fedorov's most daunting projects: the task of collecting every last particle of every last ancestor back to Adam and resynthesizing their bodies. According to Fedorov's vision, all matter in the universe is composed of "ancestral dust." Once man realizes this rodstvo, or fundamental interconnectedness of the entire human race through

42. Varshavskii, 260.

43. Vasily Yanovsky, “The Time of Nikolai Fedorov,” Third Hour (New York, 1976): 86. Yanovsky published a brief article, "Obshchee delo," interpreting Fedorov's ideas, in Novyi grad, no. 13 (1938): 172-74. His longer essay on Fedorov in English was featured in the Third Hour, no. 3 (1946-47) and reprinted in the final, memorial issue of the journal, cited here.

44. Yanovsky, Portativnoe bessmertie, 495. Ellipses in the original. 
all the generations, he will transcend his egocentric individuality and manifest his eternal, divine nature. What Fedorov neglected to specify, and what would be repeatedly brought into question by his future readers, is how the living can carry out the task of resurrecting the dead without destroying their own physical bodies in the process (after all, just like any other cosmic matter their bodies are made up of the particles of their predecessors). Speaking through his protagonist, Yanovsky uses Fedorov's ideas as a basis from which to pursue his own speculations on the limits of the unique personality and the impact of hereditary factors, ultimately proposing a different method of resurrecting ancestors, namely by distilling a spiritual "nucleus" common to all.

Bergson, who was idolized by the interwar generation, represented another source of permanent intellectual stimulation for Yanovsky, who often employed the concepts of spiritual and habitual memory in his fiction and directly addressed the French philosopher's ideas in his essay "Puti iskusstva" (translated as "Transreality: Towards a Theory of Art," 1960). ${ }^{45}$ This essay clarifies which parts of Bergson's legacy particularly intrigued Yanovsky, facilitating an interpretation of Bergsonian elements in his fictional works, including Portativnoe bessmertie. In "Puti isskustva" Yanovsky provides several lengthy quotations from Bergson's work on laughter (Le Rire: Essai sur la signification du comique [1900]), focusing on the notion of the creative impulse and the revelation of true reality as the highest purpose of art. Yanovsky does not hesitate to point out shortcomings in Bergson's system: while suggesting that art must contaminate us with a creative impulse, he writes, Bergson offered neither a hierarchy of creative impulses nor creative forms most suitable to our stage of development. Meanwhile, Yanovsky suggests that endowing people with an arbitrary and ill-defined creative impulse can be useless, and even harmful, if this energy is directed toward evil ends. The Omega ray miracle described in Portativnoe bessmertie can be read through the prism of Yanovsky's polemic with Bergson-“infecting" unprepared people with positive energy causes casualties, with some individuals throwing themselves out of windows due to an overwhelming attack of ecstasy.

Varshavskii's coupling of Bergson and Fedorov in his review of Portativnoe bessmertie perceptively highlights not only Yanovsky's appreciation of the two philosophers but also his assessment of their compatibility. Yanovsky maintained that Fedorov and Bergson acutely sensed the need to transform civilization, to revitalize it through a creative collaboration between God and mankind. For that reason, "Bergson's formula, God created man and man created the machine, is fully acceptable to Fedorov." 46

Portativnoe bessmertie at once summarizes and transcends the main motifs of Yanovsky's interwar writing, in which the protagonist's identity as an émigré loses its centrality against the backdrop of philosophical speculations and a fantastical dénouement. The hybrid genre of this experimental novel-composed of heterogeneous discourses, between fiction and nonfiction,

45. Vassily Yanovsky, "Puti iskusstva," Mosty, no. 4 (1960). In the most direct way, Bergson's work on memory informs the plot of Yanovsky's Cheliust' emigranta, New Review 49-50 (1957).

46. “The Time of Nikolai Fedorov,” 90. 
and blending confession and autobiography, theology, science fiction, utopia and dystopia-became emblematic of Yanovsky's works written in America. While during his later period he continued to engage with the Russian spiritual tradition (in particular, the works of Fedorov, Vasilii Rozanov, and Nikolai Berdiaev), he progressively emphasized its universal dimension through dynamic narratives addressed to a more global readership.

The seemingly effortless border crossing of transnational writers often turns out to be an illusion, and their narratives can reveal a profound anxiety over the disappearance of a stable identity. Perhaps for this reason transnational fiction is often populated by monsters. In Rachel Trousdale's words, "Monsters embody the anxieties of hybridity, the risk that fusion will turn out to be mere pastiche and the danger that the hybrid individual will be sterile, disfigured, or outcast." ${ }^{\prime 7}$ Significantly, Yanovsky's first artistic response to America was a Kafkaesque novel about metamorphosis, Amerikanskii opyt (American Experience, 1946-48). This is a story about a classic transnational: half-Russian and half-French, Bob Caster spends his childhood in America and the following thirty years shuttling between different countries in Europe. Upon returning to the United States he is unable to settle into his homeland, as his understanding of "real America" is constantly challenged. He suddenly undergoes a miraculous transformation, waking up one morning to discover that he has become a black man. An outsider from the start, he is now the ultimate misfit, especially because one spot on his body retains its original color, serving as a secret marker of his hybrid racial status. The main philosophical questions behind this surreal plot are what constitutes identity and whether the core of the individual disappears with a change of race or existential circumstances. By posing these questions Yanovsky inadvertently touches upon one of the most contested claims of postmodern transnational theorists, who regard race, ethnicity, and even gender as the arbitrary, culturally constructed "building blocks" of identity.

In addition to dramatizing a number of motifs that later came to be associated with the transnational canon (such as weirdness, metamorphosis, mutation, and displacement), the novel also creatively thematizes the trope of navigation. Stephen Clingman argues that "the transnational is intrinsically navigational," expressing instability and perpetual movement. ${ }^{48}$ In the epilogue, Bob Caster, finally cured of his mysterious blackness, becomes an itinerant preacher and the leader of a new sect predicated upon members ceaselessly sailing around the world, with a "settled" mode of existence regarded as a sin. The novel thus concludes with a vision of a deracinated life, outside any state, nation, continent, or, indeed, terra firma. ${ }^{49}$ Like Portativnoe bessmertie, Amerikanskii opyt ends on an ironic note: Caster's metaphysi-

47. Trousdale, Nabokov, Rushdie, and the Transnational Imagination, 192.

48. Clingman, 21.

49. At about the same time that Yanovsky was working on Amerikanskii opyt, the aesthetics of navigation found striking artistic expression in Le Corbusier's famous Housing Unit (Unité d'habitation, the best known of which, Cité radieuse, was built in Marseille between 1946 and 1952). An architect with a global vision who spent much of his life travelling around the world, Le Corbusier conceived of this impressive block of flats as an ocean liner. Designing the roof as a deck, with ventilation stacks resembling chimneys, a swim- 
cal quest finds false resolution in the creation of a fundraising society with a vaguely "spiritual" agenda which organizes public shows attended by the press. When asked by journalists why the sect leaders need money if they reject private property, Caster answers, "To build more ships.” Through his invention of "perpetual sailing" as a lucrative business model, he paradoxically realizes his American identity and, presumably, finally finds his roots. The novel's ending thus reflects its author's skeptical attitude toward "Americanism," which he equates with the mercenary spirit and the trivialization of philosophical ideas.

The language of the novel, distinguished by frequent code-switching, is in and of itself an iconic representation of hybridity. Addressed to a Russian reader with some knowledge of the English language and American reality, the novel contains a number of English loan words, often "Russified" by the addition of a Russian case ending. ${ }^{50}$ This language imitates the speech of recent immigrants who still communicate in their native idiom but, for the sake of efficiency, use English words for markedly foreign concepts with no readily available Russian equivalents. Most of the foreign lexical items fall into one of several semantic groups: New York topography, medicine, and government bureaucracy. Sometimes Yanovsky engages in a witty translingual game that serves to highlight discrepancies between Russian and American mentalities. For example, describing Bob Caster's stay in a prison-like psychiatric facility, Yanovsky saturates his text with medical terminology. In the chapter with the English title "Pronouncer of Death," he includes detailed instructions for hospital staff on the proper handling of corpses (clearly drawn from his own professional experience in various American hospitals). ${ }^{51}$ This passage is deliberately left untranslated, giving the text a foreign feel. Yanovsky thus not only re-creates the feeling of bewilderment that an émigré may experience when confronted with an unfamiliar reality (especially in such a morbid context) but also contrasts American and Russian sensibilities and cultural codes, ridiculing Americans' ostensibly rationalistic attitude toward the "mystery of death." At the same time, this grotesque passage explodes the Russian taboos surrounding death that created a glaring lack of appropriate and straightforward vocabulary. ${ }^{52}$ By alternating between these two linguistic codes Yanovsky demonstrates a special sensitivity to the deficiencies of the respective languages, one that distinguishes translingual individuals.

The émigré audience did not appreciate Yanovsky's lack of engagement

ming pool, a running track, and spaces for enjoying the Mediterranean view, he found an eloquent architectural language to express the idea of life as an endless voyage.

50. For example, "No v Central Park'e sneg eshche lezhal”; "prikliucheniia poslednego week-end'a"; "V etot vecher povzdorili iz-za party u Dzho.” Emphases added.

51. "Place the patient in a recumbent position, straighten the limbs.... If the eyes did not remain closed, pull out the lower eyelid so as to make a pocket, place a few shreds of cotton or a small piece of thin paper in this pocket and bring the upper lid down over it.... Cross the hands over the chest and tie them together." V. Yanovsky, "Amerikanskii opyt," New Review 18 (1948): 129.

52. In his novel Le Testament français (1960), contemporary Russian-born francophone author Andreï Makine contemplates a similar dearth in Russian (especially compared to French) of appropriate vocabulary related to physical love, which leads to either prudish silencing of sex-related issues or to the use of obscenities. 
with the national thematic context. Apart from regularly contributing to the New Review, he failed to integrate into the publishing network of the Russian diaspora. Fedor Stepun attributed Yanovsky's books' unpopularity to the distance that separates them from the mainstream canon of Russian literature (Lev Tolstoi, Ivan Turgenev, Ivan Goncharov, Anton Chekhov, Ivan Bunin). ${ }^{53}$ This judgment reflects the gap between Yanovsky's objectives and the émigré audience's horizon of expectations (indirectly assessed by Stepun as conservative and hostile to any deviation from classical national models).

Frustrated by the indifference of the diaspora community, Yanovsky eventually decided to appeal directly to international readers by publishing his work in English. Elizabeth Klosty Beaujour estimates that the reason for his embracing English was, in the first instance, his "concern to transmit to readers the essence of his philosophical message" rather than any "inherent attraction" to the new adopted tongue. ${ }^{54}$ To some extent, Yanovsky's language shift may have been prepared by his engagement with the Third Hour and the example of the group's leader, Izwolsky, who published with equal frequency in three languages. Beaujour suggests that "the ease with which Iswolsky moved among Russian, French and English" was "in large part the result of her overarching concern with the ecumenical Christian message.” Indeed, even Izwolsky's conversion to Catholicism "would also seem to have freed her from the attachment that Orthodox writers sometimes have to the Russian language as a privileged vessel of spiritual truth." 55

Nor was it a "privileged vessel of spiritual truth" for Yanovsky, given his own ecumenical stance and desire to address people of diverse backgrounds. As a transnational writer, his attitude toward his native language differed sharply from that of the émigré majority, who attributed to Russian a nearsacred status and saw its preservation as a guarantee of their cultural survival.

Yanovsky's very first attempt at publishing in English arguably yielded his best novel of the American period, Po tu storonu vremeni, released in English translation under the title No Man's Time (1967). ${ }^{56}$ His wife, Isabella Levitin, initiated the translation, for which she collaborated with Roger Nyle Parris, but it is plausible that Yanovsky was also involved in the effort, within the limits of his language proficiency. ${ }^{57}$ W. H. Auden, Yanovsky's close friend of thirty years, played an important role in the success of No Man's Time, recommending it to publishers and supplying a foreword in which he defined the novel as fantasy.

The genre of No Man's Time is in fact quite complex. Critics have called it an "allegory or nonsense-fable," "a parable of Everyman and the human predicament," and even a "sacro-scientific detective novel," tracing it to diverse

53. Fedor Stepun, review of Cheliust' emigranta, by V. S. Yanovsky, New Review 54 (1958): 296.

54. Elizabeth Klosty Beaujour, Alien Tongues: Bilingual Russian Writers of the "First" Emigration (Ithaca, 1989), 149.

55. Ibid., 153.

56. V. S. Yanovsky, No Man's Time, trans. Isabella Levitin and Roger Nyle Parris (New York, 1967).

57. Yanovsky never achieved near-native fluency, and although later he wrote books in English, his wife remained his permanent and indispensable editor. 
literary lineages, from Jonathan Swift and Lewis Carroll to J. R. R. Tolkien and Nabokov..$^{58}$ It has a suspenseful plot and is a far cry from the introspective and plotless prose of Yanovsky's earlier period, although the quest for identity still constitutes the main philosophical focus. The protagonist, whose Russian origin is almost completely glossed over, circulates between two parallel worlds: a quasi-utopian Canadian settlement, unspoiled by modern civilization, that is a strange cross between a patriarchal Russian village (possibly Dukhobor) and an Amish community, and the dystopian world of the urban metropolis (Chicago and New York). With respect to this dichotomy, the protagonist has two alternative identities and two alternative names.

Cornelius Yamb comes to the mysterious village to track down a certain Bruno, the unlikely heir to an immense fortune. Upon arrival, he is unexpectedly welcomed by his wife, of whom he has no recollection, who calls him Conrad Jamb and tells him that he has been missing for a number of years. Thus Cornelius/Conrad begins the long process of embracing and reconciling his alternative selves, confirming a basic premise underlying transnational discourse, namely that "identity is a process, not a stable product, subject to reaffirmation and reconstruction." 59

Meanwhile, Bruno turns out to be a prophet of sorts. The object of Conrad's original, pecuniary quest, Bruno has become a guru who helps him to revisit the basic notions of life, death, time, memory, personality, unity, and separation, and thereby to complete his transformation. Apparently able to remember the history of the entire universe since the day of creation, Bruno advocates the pluralism of personality. Even his nickname is "We," echoing Fedorov's preference for this pronoun over the egocentric "I." ${ }^{60}$ Bruno's revelations can be traced to other sources, from the Russian idea of sobornost' and Vladimir Solov'ev's concept of vseedinstvo, to the theories of Bruno's Renaissance-era namesake, Giordano Bruno, who articulated the infinity of the universe and the plurality of its centers, and the idea of anamnesis in its Platonic or Hindu senses. Similar views are espoused by a blind minister, who instructs the villagers in the prayer-house on Sundays.

Paraphrasing Bergson, he states that our "immortal" and "everlasting" personality is "obscured" by short-term, trivial memory, which cannot serve as a reliable reference point because it does not extend beyond infancy. ${ }^{61}$ Original, primordial unity can only be reached through cosmic memory. Through his characters, Yanovsky challenges the linear, unidirectional conception of memory and time, logic, and the rule of cause and effect. Past, present, and

58. For a concise survey of the novel's critical reception see: B. Hal May, "Yanovsky, V(assily) S(emenovich) 1906- (Basile S. Yanovsky)," in Contemporary Authors: A BioBibliographical Guide to Current Writers in Fiction, General Nonfiction, Poetry, Journalism, Drama, Motion Pictures, Television, and Other Fields, ed. Frances C. Locher, vols. 97-100 (Detroit, Mich., 1981), 577-79.

59. Trousdale, Nabokov, Rushdie, and the Transnational Imagination, 194.

60. "Fedorov never uses the pronoun 'I' in his works except to denigrate the concept of individualism. And the 'we' he uses is not the lofty, editorial 'we' but the 'we' of the nameless collective, the mass of the unnoticed, the victims of nature and history." George M. Young, Jr., Nikolai F. Fedorov: An Introduction (Belmont, Mass., 1979), 85.

61. No Man's Time, 57-60. 
future are interchangeable, as illustrated by the hiatus between January 1 and 13 , when time in the mysterious village stands still, allowing people to go back and correct their transgressions. This is precisely the period defined as "no man's time." The text also creatively incorporates a number of contemporary theories about the structure of the cosmos, the relativity of time and space, the transformation of matter, and supersonic speed, reflecting Yanovsky's interest in science.

The novel therefore provides a fictional framework for Yanovsky's insights into mystical reality, which he also expressed elsewhere. In his treatise “Transreality," Yanovsky writes that we must endeavor to recall that reality in which our soul dwelled "before the first concentration of cosmic gases" and to "remember that reality which exists ... beyond the imagined horizon of the present." Developing Bergson's thesis that art is the most efficient and refined method of unmasking true reality, Yanovsky argues that art should not limit itself to psychology or mimesis: "So-called realistic art [is] an art paralyzed by the shadows and specters of the night. Most responsible for this decline was the psychological novel. For the life of the soul and the body is not covered by psychology." 62 In his aforementioned review, Stepun pointed out one more perceived "weakness" of Yanovsky's prose, which alienates it from the Russian literary tradition: "Yanovsky's novels and tales are distinguished by neither stereoscopic plasticity of descriptions of the external world nor by an in-depth exploration of human souls; he is neither a chronicler of daily life [bytovik] nor a psychologist." ${ }^{3} 3$ While Stepun's claim that the essence of Russian literature is circumscribed by psychological realism is in itself highly questionable, his criticism was certainly misplaced in this particular instance, as Yanovsky clearly had no interest in writing himself into the national canon by reproducing a stock model. As follows from the above quotations, his conception of art was modern and highly unconventional. It can be more appropriately assessed against the backdrop of the transnational trend in twentieth-century aesthetic thinking that sought to replace the dated realistic method, the leftover of a discredited positivism, with a breakthrough into supreme reality-beyond rationality and sensual perception. Auden begins his foreword to No Man's Time by distinguishing between two types of writers, whom he defines as creators of "primary" (physical) and "secondary" (spiritual) worlds, classifying Yanovsky among the latter. ${ }^{64}$

As opposed to Portativnoe bessmertie, in which the world was to be saved from collapse through a dubious technological invention, No Man's Time offers a different path, suggesting that death can be overcome spiritually by renouncing routine forms of thinking and through humanity's self-realization in a creative act. Bruno formulates the following plan to save earthly civilization, echoing Fedorov's vision of cosmic expansion: "All must be removed to other points in the cosmos. ... Other heavenly bodies must be infected with our cells and rays.... Inseminate another universe, create new worlds, bring life beyond the Milky Way and even to the limits of matter, to the end

62. BAR: Ms Coll. Yanovsky. Box 17. Emphasis in the original.

63. Stepun, 296.

64. W. H. Auden, "Foreword,” No Man's Time, 7. 
of our time and space where light does not reach." ${ }^{\prime 5}$ The novel contains even more transparent allusions to Fedorov, including his vision of the resurrection of ancestors by synthesizing them from atoms and molecules. Yanovsky believed that while everyone can contribute to this "common task" in their own original way, creative personalities are endowed with special potential. As he wrote in his essay "The Time of Nikolai Fedorov,"

Concealed in the semen of every man, the "nucleus" of many long-departed ancestors is alive. ... We ought to cultivate our memory, become fully perceptive of our past, securely fix all the traits of our loved ones, external as well as internal. This is a task that belongs to art. Unexpectedly, we find here at Fedorov's side such artists as Marcel Proust, whose À la recherché du temps perdu is properly speaking an attempt at resurrection. But if such an attempt were successful, then the "time" had not been "lost." All roads-of egotism, morals and religion-cross at this point: resurgence. There are no other themes. There is no other cause. ${ }^{66}$

Art could never be reduced to a purely aesthetic function for Yanovsky, and his entire body of work eloquently testifies to the fact that he aspired to contribute to this universal cause himself.

The publication history of No Man's Time, which was released in English decades before the original appeared in Russia, illustrates the trope of translation as it is used in contemporary critical discourse to conceptualize processes inherent in transnational writing. Most likely written with a view to being published in English, the novel was consciously rendered translatable. While neither the Russian nor the English version of the novel is distinguished by remarkable stylistic finesse, both texts employ a similar mode of signification and are built on the same structural patterns inherited from an underlying prior "language." ${ }^{.67}$ The novel's translatability also hinges upon its focus on the universal human dream of belonging and forgiveness, recovering one's true home and authentic self, cancelling time and pain, and "resurrecting" loved ones (if not literally, à la Fedorov, at least through spiritual effort and memory). These are basic human sentiments that appeal to people of all cultures, regardless of any national specificity. Toward the end of the novel, Cornelius, consumed by despair and anxiety, has a vision of returning to his childhood home. He pictures his father and sisters (all long dead) and realizes that their eyes are the same as the eyes of the villagers ("immobile, tranquil, silent, as if afraid to tell the whole truth"). ${ }^{68}$ At that moment he decides to return to his North American family. Like his remote Russian home, the Canadian village exists outside linear time, in a mythic chronotope, beyond the dichotomy of life and death. Both are just variations of the same set of archetypal experiences that play out for Cornelius/Conrad in different incarnations and in seemingly different worlds. This time, he returns to the village with a bit more

65. No Man's Time, 120.

66. "The Time of Nikolai Fedorov," 89.

67. This differs from Nabokov's strategy of self-translation, which resulted in the creation of "non-identical doubles," since the writer deliberately modified his texts to cater to either Russian or American audiences.

68. No Man's Time, 215. 
awareness and a better memory of this alternative version of existence. However, the circular composition of the novel-bringing the protagonist back to the starting point at the end of the narrative-suggests another possible round of delusions, departures, false starts, suffering, remorse, and eventual return. Despite the apparent simplicity of this yearning for a primordial wholeness, it is expressed by Yanovsky in a "cosmic" language steeped in mysticism and scientific theories.

In his subsequent novels and nonfiction Yanovsky continued to explore human life as integrated into a cosmic flow, challenging conventional boundaries between life and death, past and future, self and other, terrestrial civilization and remote galaxies. ${ }^{69}$ Because of this universal dimension of his writing, he would be an odd bedfellow of the group of translingual Russian-born American writers who have become a conspicuous phenomenon in contemporary letters (including Gary Shteyngart, Olga Grushin, Sana Krasikov, Irina Reyn, David Bezmozgis, and Ellen Litman). At first sight, Yanovsky could qualify as their precursor (and a more direct one than Nabokov, to whom these authors are routinely compared): native speakers of Russian, they also appropriated English as their literary language after immigrating and have challenged "any notion of a fixed ethnic essence."70 Furthermore, although many of them are Jews, for the most part they are reluctant to engage with their Jewish identity and certainly show no affinity for Judaism. However, as Adrian Wanner demonstrates, these translingual writers are eager to capitalize on their Russianness, turning it into a valued commodity. While creating a distinctly Russian self-representation, they seek to meet the specific demands of their host nation, and through allusions to Russian classics they exploit the prestige of Russian high culture. ${ }^{71}$ Yanovsky, on the contrary, did not project a Russian persona, nor did he try to captivate western readers with inside knowledge of an "exotic" Russia, although his allusions to Russian writers and thinkers are just as important as his references to a western cultural heritage. Moreover, as opposed to the contemporary Russian American writers who promote themselves as "a group reinforcing and feeding off each other's success," Yanovsky failed to fully integrate into the Russian diaspora in America. ${ }^{72}$ If he is to be studied in any group context, it should rather be the Third Hour intellectual platform and its specific brand of transnationalism. However, the lack of a common aesthetic language and the extreme stylistic heterogeneity of its individual group members prevented them from advancing a distinct literary trend.

An examination of Yanovsky's prose demonstrates the diversity and flexibility of modernist transnational models. In his works of the interwar period Yanovsky embraced the artistic code of the Paris School, a transnational community whose cultural identity was informed by the experience of deracination, avant-garde sensibilities, and the cosmopolitan atmosphere of

69. His later works include Of Light and Sounding Brass (1972), The Dark Fields of Venus: From a Doctor's Logbook (1973), and The Great Transfer (1974).

70. Wanner, Out of Russia, 18.

71. Ibid., 15, 190, 192.

72. Ibid., 188. 
the French capital. In America his writing transcended not only a national framework but also any alliance defined by specific generational affinities or the impact of historical events. Determined to speak a more universal language and address a more global audience, he blended dynamic fictional patterns with insights into science, medicine, and transcendental philosophy, examining human experience in the context of cosmic evolution. Yanovsky's liberal fusion of Fedorov's cosmism and Bergson's theory of memory, as well as mystical views on the transmigration of the soul and ecumenical Christianity, produced a hybrid narrative, one that is open to further interpretations, illustrating the inherently dynamic, dialogic, and inclusive nature of transnational texts. This ambitious agenda had to be rendered in a mixture of fictional and nonfictional genres, and "high" and "low" styles, challenging conventional hierarchies and foreshadowing the collapse of all binaries in late twentieth-century literature. Although Yanovsky chose to write bilingually, his narratives highlight the primary importance for transnational literature of the translatability of its underlying concepts and modes of signification. The writer also pursued a parallel path of expanding the elasticity of his native idiom, creating a vernacular better adapted to reflect the diaspora's translingual consciousness. Yanovsky's engagement with boundaries of all sorts demonstrates the relevance for diaspora writing of the hybridity, plurality, and fusion that underlie transnational discourse. 